\title{
Thiazolidinediones Repress ob Gene Expression in Rodents Via Activation of Peroxisome Proliferator-activated Receptor $\gamma$
}

\author{
Piet De Vos, ${ }^{*}$ Anne-Marie Lefebvre, ${ }^{\star}$ Stephen G. Miller, ${ }^{\ddagger}$ Michele Guerre-Millo, ${ }^{\S}$ Kenneth Wong, ${ }^{\ddagger}$ Regis Saladin, ${ }^{\star}$ \\ Lawrence G. Hamann, ${ }^{\ddagger}$ Bart Staels, ${ }^{*}$ Michael R. Briggs, ${ }^{\ddagger}$ and Johan Auwerx ${ }^{\star}$ \\ *INSERM U325 and Departement d'Atherosclerose, Institut Pasteur, F-59019 Lille, France; ${ }^{\ddagger}$ Ligand Pharmaceuticals, Inc., \\ San Diego, California 92121-3016; and ${ }^{\S}$ INSERM U177, Institut des Cordeliers, 75006 Paris, France
}

\begin{abstract}
The $o b$ gene product, leptin, is a signaling factor regulating body weight and energy balance. $o b$ gene expression in rodents is increased in obesity and is regulated by feeding patterns and hormones, such as insulin and glucocorticoids. In humans with gross obesity, $o b$ mRNA levels are higher, but other modulators of human $o b$ expression are unknown. In view of the importance of peroxisome proliferator-activated receptor $\gamma(\operatorname{PPAR} \gamma)$ in adipocyte differentiation, we analyzed whether $o b$ gene expression is subject to regulation by factors activating PPARs. Treatment of rats with the PPAR $\alpha$ activator fenofibrate did not change adipose tissue and body weight and had no significant effect on $o b$ mRNA levels. However, administration of the thiazolidinedione BRL49653, a PPAR $\gamma$ ligand, increased food intake and adipose tissue weight while reducing $o b \mathrm{mRNA}$ levels in rats in a dose-dependent manner. The inhibitory action of the thiazolidinedione BRL49653 on $o b$ mRNA levels was also observed in vitro. Thiazolidinediones reduced the expression of the human $o b$ promoter in primary adipocytes, however, in undifferentiated 3T3-L1 preadipocytes lacking endogenous PPAR $\gamma$, cotransfection of PPAR $\gamma$ was required to observe the decrease. In conclusion, these data suggest that PPAR $\gamma$ activators reduce $o b$ mRNA levels through an effect of PPAR $\gamma$ on the $o b$ promoter. (J. Clin. Invest. 1996. 98: 1004-1009.) Key words: obesity • antidiabetic • adipocyte • adipose
\end{abstract}

\section{Introduction}

Obesity, a disorder of energy balance, represents a major health problem and is usually associated with complications including cardiovascular disease, diabetes, and an increased mortality rate (1). Obesity or predisposition to obesity has a strong genetic component (2). In the $o b / o b$ mouse, a single gene mutation results in profound obesity that is often accompanied by diabetes (3). Using positional cloning techniques,

Address correspondence to Michael R. Briggs, Ligand Pharmaceuticals, Inc., 9393 Towne Centre Drive, San Diego, CA 92121-3016. Phone: 619-550-7886; FAX: 619-535-3906; E-mail: mbriggs@ligand.com or Johan Auwerx, INSERM U325, Departement d'Atherosclerose, Institut Pasteur, 1 Rue Calmette, F-59019 Lille, France.

Received for publication 29 February 1996 and accepted in revised form 19 June 1996.

J. Clin. Invest.

(C) The American Society for Clinical Investigation, Inc.

0021-9738/96/08/1004/06 \$2.00

Volume 98, Number 4, August 1996, 1004-1009
Friedman and colleagues identified the mouse $o b$ gene and its human homologue (4) and demonstrated that expression of the $o b$ gene is limited to adipose tissue. In mutant SM/Ckc$+{ }^{\mathrm{Dac}} o b^{2 \mathrm{~J}} / o b^{2 \mathrm{~J}}$ mice, a genomic alteration results in the complete absence of $o b$ mRNA, whereas in C57BL/6J-ob/ob mice, a nonsense mutation results in a truncated, nonfunctional protein. Studies with specific antibodies confirmed the presence of the $o b$ gene product, leptin, in plasma of normal mice and its absence in plasma of $o b / o b$ mutants (5). Before the identification of the $o b$ gene, a role for leptin as a satiety factor was proposed based on data derived from parabiosis experiments (6). When $o b / o b$ mice were made parabiotic with normal mice, they curbed their eating and lost weight, suggesting that they were responsive to a blood-borne satiety factor produced by the normal partner (6). Furthermore, leptin injection reduces food intake, increases energy expenditure, induces weight loss, and normalizes metabolic parameters such as insulin and glucose in wild-type, diet-induced obese and C57BL/6J ob/ob mice $(5,7-10)$.

A potential mechanism of leptin's signaling action was elucidated recently when a leptin receptor was cloned $(11,12)$. This receptor is related to the gp130 signal transducing component of the IL-6, G-CSF, and LIF cytokine receptors (11). The receptor is highly expressed in the choroid plexus and maps to a position on mouse chromosome 4 encompassing the $d b$ locus. It is therefore tempting to speculate that leptin provides the central nervous system with a signal triggering multiple effector pathways leading to leptin's pleiotropic effects.

To completely understand leptin's role in energy metabolism, it is necessary to delineate the factors involved in $o b$ gene regulation. Recent studies have demonstrated that the expression of the $o b$ gene is itself controlled by the nutritional status of the animal. Fasting reduces, whereas food intake increases, $o b$ gene expression (13-16), an effect accounted for by changes in plasma insulin levels $(14,16)$. Glucocorticoids have also been shown to regulate $o b$ gene expression $(17,18)$. Furthermore, in overtly obese humans (19-23) and in several animal models of obesity, such as the $d b / d b$ mouse, Zucker $f a / f a$ rats, and VMH-lesioned rats (5, 13, 24-28), which do not appear to respond to leptin, $o b$ mRNA and circulating leptin levels are increased. These findings suggest that upregulation of $o b$ mRNA levels occurs as a homeostatic mechanism.

Since the $o b$ gene is exclusively expressed in adipocytes, we have initiated studies to examine the role of adipogenic factors in the expression and regulation of the $o b$ gene. The expression of two important adipocyte transcription factors, peroxisome proliferator-activated receptor $\gamma(\operatorname{PPAR} \gamma)^{1}$ and $\mathrm{C} / \mathrm{EBP} \alpha$, is induced during adipocyte differentiation and these factors

1. Abbreviations used in this paper: $\mathrm{C} / \mathrm{EBP}, \mathrm{CAAT} / \mathrm{enhancer}$ binding protein; PPAR, peroxisome proliferator-activated receptor; PPRE, PPAR response element. 
are maintained in the mature adipocyte. Several adipocytespecific genes have binding sites for these factors in their promoters and have been shown to be transcriptionally responsive to chemical modulators of these factors (reviewed in reference 29 ). Recent studies by our group and others have characterized the role of $\mathrm{C} / \mathrm{EBP} \alpha$ in $o b$ gene expression, an effect mediated by a C/EBP site in the proximal $o b$ gene promoter (30, 31 ). The present study was undertaken to better understand the role of PPAR $\gamma$, the other key transcription factor implicated in the determination of the adipocyte phenotype, in $o b$ gene expression. In these studies, we demonstrate that expression of the $o b$ gene is reduced by PPAR $\gamma$ and its activators both in vivo and in vitro.

\section{Methods}

Reagents. BRL 49653 was synthesized at Ligand Pharmaceuticals (San Diego, CA), whereas fenofibrate was a generous gift of Dr. Alan Edgar of Fournier (Dijon, France). All other reagents were obtained from the usual sources.

Animal studies. Adult Sprague-Dawley rats were divided in groups of four animals each. They were group housed and accustomed to a 12:12 h day-night illumination cycle (light from 8 a.m. to 8 p.m.). In one series of experiments, the effects of BRL 49653 were analyzed. In the first study, rats received BRL $49653(1,2$, or $5 \mathrm{mg} / \mathrm{kg}$ per d) or vehicle alone (1\% carboxymethylcellulose) for $7 \mathrm{~d}$ by gavage. In a subsequent experiment, rats were dosed with either 5 or 10 $\mathrm{mg} / \mathrm{kg}$ per d. In a third study, controls were compared with animals that received $0.5 \% \mathrm{wt} / \mathrm{wt}$ of fenofibrate mixed with their food over 14 d. In a final study, we analyzed adipose tissue $o b$ mRNA levels in rats fed a high-fat diet containing $20 \%$ hydrogenated coconut oil (controls) or $20 \%$ menhaden (fish) oil for $3 \mathrm{mo}$. All animals were killed by exsanguination under ether anesthesia between 8 and 10 a.m. Epididymal adipose tissue was removed, rinsed with $0.9 \% \mathrm{NaCl}$, and frozen in liquid nitrogen until RNA preparation.

Cell culture. Primary rat adipocytes were obtained exactly as described by Hajduch et al. (32). Standard cell culture conditions were used to maintain 3T3-L1 cells obtained from American Type Culture Collection (Rockville, MD). BRL 49653 and fenofibric acid (in DMSO) were added to the medium at the appropriate concentrations for the times indicated while control cells received vehicle only.

$m R N A$ analysis. RNA preparation, Northern and dot blot hybridizations, and quantification of total cellular RNA were performed as described previously (16). $o b$ mRNA was detected using a labeled mouse $o b$ cDNA fragment spanning nucleotides +50 to +659 (17), and a human $\gamma$-actin cDNA clone (33) was used as a control for normalization.

Analysis of promoter activity. To test the activity of the human $o b$ promoter in vitro, reporter constructs were made. A 7-kb HindIII fragment of the human genomic Pl clone 5135 hybridizing to an oligo containing the $20 \mathrm{bp}$ located at the $5^{\prime}$ end of the $o b$ cDNA was subcloned into the HindIII site of pBluescript (Stratagene Inc., San Diego, CA). From this construct, a 3-kb fragment, containing sequences from $-2924\left(5^{\prime}\right.$ HindIII site $)$ to +31 relative to the transcription start site, was amplified by PCR with a T7 primer and SMREV2 (5'CGCGGGAAGCTTGCCTTGCAACCGTTGGCGCTGCG-3'). The PCR product was digested with HindIII and ligated into the HindIII site of the promoterless luciferase reporter vector pGL3-Basic (Promega Corp., Madison, WI) to generate pGL3-OB1 and sequenced to confirm orientation $(30,34)$. The hamster pSG5-cgP-PAR $\gamma$ expression vector has been described elsewhere (35). Transfections were performed using either standard calcium phosphate precipitation techniques for 3T3-L1 preadipocytes (36) or electroporation for primary adipocytes (37). A cytomegalovirus-driven $\beta$-galactosidase expression vector was used to normalize for transfection efficiency. Luciferase assays were carried out exactly as described previously (37).

\section{Results}

Food intake and adipose tissue weights increase and ob $m R N A$ levels decrease after administration of PPAR $\mathrm{but}$ not PPAR $\alpha$ activators to rats. Adipocyte differentiation has been shown to be determined by the coordinately acting transcription factors PPAR $\gamma(30,38,39)$ and various members of the C/EBP family (reviewed in reference 40). Previous studies by our group (30) and others (31) demonstrated the critical role of $\mathrm{C} / \mathrm{EBP} \alpha$ in the expression of the $o b$ gene. In these studies, we addressed the role of PPAR $\gamma$ in $o b$ gene regulation. We first tested the effects of the antidiabetic thiazolidinedione BRL 49653, previously shown to be a high affinity ligand for PPAR $\gamma(41,42)$, on the expression of the $o b$ gene in vivo in rats. In animals receiving BRL 49653 at increasing doses $(0,1,2$, and $5 \mathrm{mg} / \mathrm{kg}$ per d) over $7 \mathrm{~d}$, no change in either body or liver weight was observed (Table I). However, a dose-dependent increase in epidydimal fat pad weight was observed after BRL 49653 treatment (Table I). These observations are consistent with previously reported activities of the thiazolidinedione antidiabetic agents to induce adipocyte differentiation and increase adipose tissue mass (43-47). In this experiment, which used relatively low doses of BRL, food intake showed a tendency to decrease, although no statistical significance was obtained. To unequivocally establish that BRL 49653 had an effect on food intake we administered higher doses of BRL 49653 (5, 10, $20 \mathrm{mg} / \mathrm{kg}$ per d) to rats over $7 \mathrm{~d}$ and recorded food intake on a daily basis. In this experiment, administration of BRL at doses of 5, 10, or 20 $\mathrm{mg} / \mathrm{kg}$ per $\mathrm{d}$ was associated with a significant increase in food intake (Fig. 1).

To analyze whether the effect of thiazolidinediones on adipose tissue involves changes in $o b$ expression, we analyzed $o b$ mRNA in epidydimal fat pads of these rats. $o b$ mRNA levels decreased by $40 \%$ in rats treated with BRL 49653 at $5 \mathrm{mg} / \mathrm{kg}$ per d (Fig. 2). Other potential conditions resulting in activation of PPAR $\gamma$, such as administration of a diet enriched in fish oils ( $20 \% \mathrm{wt} / \mathrm{wt}$ in food, $3 \mathrm{mo}$ ), also decreased $o b$ mRNA expression significantly by $33 \%$ (Fig. 2). This indicates a possible role for fatty acid-derived PPAR activators in the regulation of $o b$ gene expression. In contrast to the results obtained with thiazolidinediones and fish oils, administration of the PPAR $\alpha$ activator, fenofibrate $(0.5 \% \mathrm{wt} / \mathrm{wt}$ in food for $14 \mathrm{~d})$, did not result in a reduction of $o b$ mRNA levels (Fig. 2). Treatment of ani-

Table I. Effects of Administration of Different Doses of BRL 49653 on Body Mass, Liver Weight, and Weight of the Epidydimal Fat Pad

\begin{tabular}{lccc}
\hline & Body mass & Epidydimal fat & Liver \\
\hline & grams & grams & grams \\
Control & $344 \pm 22$ & $2.5 \pm 0.3$ & $16.8 \pm 1.3$ \\
$\begin{array}{l}\text { BRL 49653 } \\
\quad(1 \mathrm{mg} / \mathrm{kg} \text { per d })\end{array}$ & $355 \pm 21$ & $3.3 \pm 0.2^{*}$ & $17.9 \pm 1.3$ \\
$\begin{array}{l}\text { BRL 49653 } \\
\quad(2 \mathrm{mg} / \mathrm{kg} \text { per d })\end{array}$ & $361 \pm 18$ & $3.8 \pm 0.5^{*}$ & $18.9 \pm 0.6$ \\
$\begin{array}{l}\text { BRL 49653 } \\
(5 \mathrm{mg} / \mathrm{kg} \text { per d })\end{array}$ & $338 \pm 9$ & $4.0 \pm 0.6^{*}$ & $17.4 \pm 1.8$ \\
\end{tabular}

*Statistically different from control, $P<0.05$. 


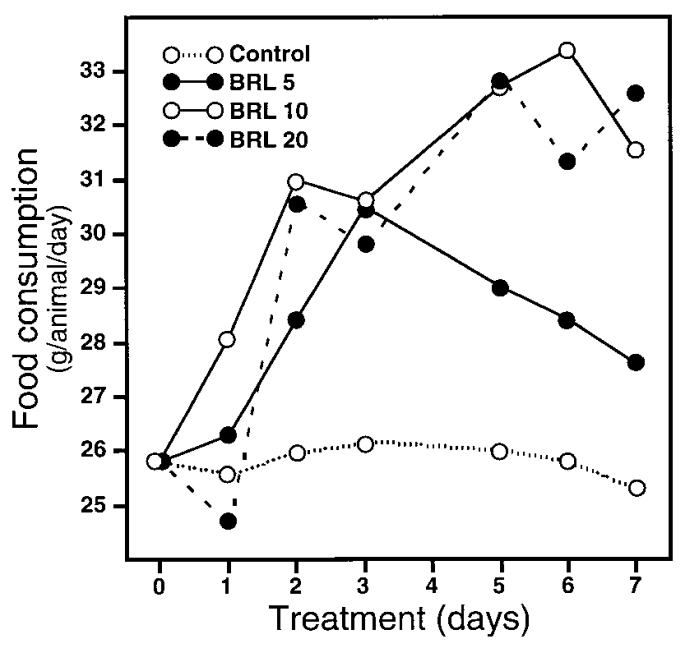

Figure 1. BRL 49653 increases food intake in rats. Rats (groups of 5) were administered either $0,5,10$, or $20 \mathrm{mg} / \mathrm{kg}$ per d of BRL 49653 and the effect on food intake was recorded daily.

mals with fenofibrate did not result in a change in body or adipose tissue weight, whereas the typical increase in liver weight (from $13.8 \pm 0.5$ to $19.7 \pm 2.5$ grams) known to occur after treatment with peroxisome proliferators such as fenofibrate was observed (48). Furthermore, this increase in liver weight was associated with a sevenfold induction in liver acylCoA oxidase mRNA levels indicating that fenofibrate was active (49) (data not shown). The effect of BRL 49653 on $o b$ mRNA expression was furthermore dose dependent, being most pronounced at a dose of $5 \mathrm{mg} / \mathrm{kg}$ per d (Fig. 3).

PPAR $\mathrm{y}$ activators control ob $m R N A$ expression in cultured primary adipocytes. To determine whether the in vivo changes in $o b$ gene expression are the result of a direct PPAR $\gamma$ effect on adipocyte $o b$ gene expression, we evaluated the effects of BRL $49653(100 \mu \mathrm{M} ; 24 \mathrm{~h})$ and the PPAR $\alpha$ selective peroxisome proliferator, fenofibric acid $(250 \mu \mathrm{M} ; 24 \mathrm{~h})$, on $o b$ mRNA expression in primary rat adipocytes. Whereas BRL 49653 reduced $o b$ mRNA expression significantly in three in-
A

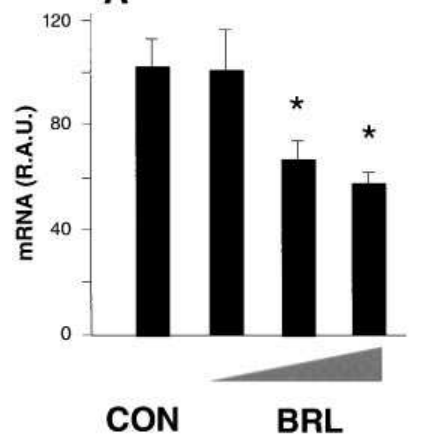

B

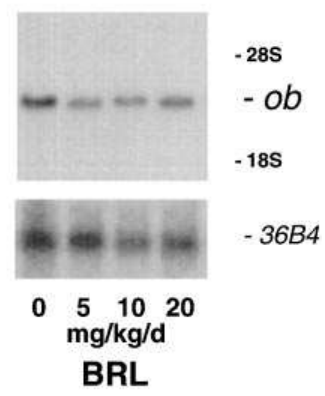

Figure 3. Dose-dependent effect of BRL 49653 on $o b$ mRNA levels. (A) Dose-dependent effect of BRL 49653 (BRL; 0, 1,2,5 mg/kg per d) administered during $7 \mathrm{~d}$ to male rats on $o b$ gene expression. Adipose tissue RNA was isolated and mRNA levels, normalized to a control mRNA, quantified as indicated in the Methods section. The mean \pm SD for four animals is shown. $* P<0.05$. (B) Representative Northern blots, from an independent experiment, probed with an $o b$ specific probe (top) or a probe for 36B4 (bottom), a gene whose expression is not affected by the differentiation state (38).

dependent experiments, no effect of fenofibrate on $o b$ mRNA levels was detected (Fig. 4). These results thus suggest that the in vivo effects of the PPAR $\gamma$ ligand BRL 49653 are due to a direct cellular effect on adipocyte $o b$ gene expression.

PPAR $y$ modulates the ob promoter at the transcriptional level. We next studied the effects of coexpression of PPAR $\gamma$ in the presence or absence of PPAR activators on the $\sim 3 \mathrm{~kb}$ human $o b$ promoter construct pGL3-OB1 (30). In primary rat adipocytes, cotransfection of the PPAR $\gamma$ expression vector (pSGS-cgPPAR $\gamma$ ) in the absence of activators had no effect (Fig. $5 A$ ). When the thiazolidinedione, pioglitazone, was added $(10 \mu \mathrm{M})$, a $30 \%$ decrease in $o b$ promoter activity was observed. Combination of PPAR $\gamma$ plus pioglitazone led to an additional decrease to $\sim 50 \%$ (Fig. $5 \mathrm{~A}$ ). When a more potent thiazolidinedione, such as BRL $49653(10 \mu \mathrm{M})$, was used in rat primary adipocytes, promoter activity was reduced $60 \%$ and cotransfection of PPAR $\gamma$ had no further effect, suggesting the
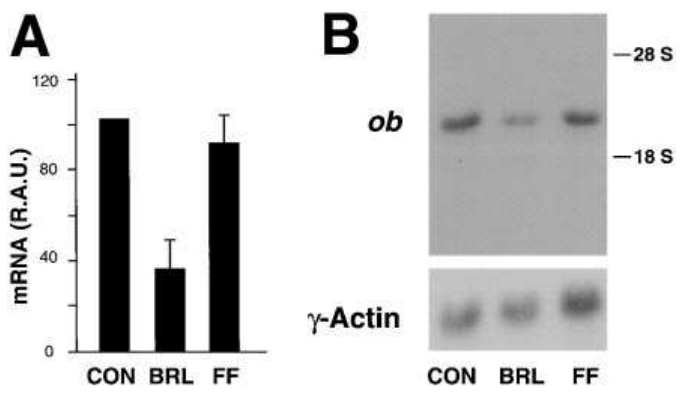

Figure 4. PPAR activators decrease $o b$ gene expression in primary adipocytes. $(A)$ Effect of treatment with BRL $49653(100 \mu \mathrm{M}, 24 \mathrm{~h})$ and fenofibric acid $(250 \mu \mathrm{M}, 24 \mathrm{~h})$ on $o b$ mRNA levels in rat primary adipocytes. RNA was isolated and quantified as indicated in the Methods section. The mean of three independent experiments is shown taking the controls as $100 \%$. The BRL 49653 effect was significant at $P<0.05$. (B) Representative Northern blot showing the effects of BRL 49653 and fenofibric acid on $o b$ mRNA levels in primary rat adipocytes. Blots were reprobed with $\gamma$-actin as a control. 
A

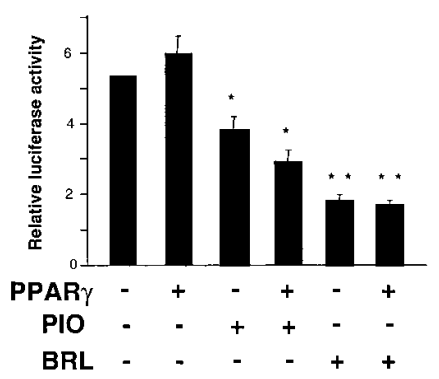

Figure 5. $o b$ promoter activity is regulated by PPAR $\gamma .(A)$ Promoter activity of the pGL3-OB1 construct was analyzed in primary rat adipocytes. Luciferase activity was determined in cells transfected with either $5 \mu \mathrm{g}$ of pSG5-cgPPAR $\gamma$ or the empty pSG5 expression vector in the presence or absence of $10 \mu \mathrm{M}$ pioglitazone or $10 \mu \mathrm{M} \mathrm{BRL}$ 49653. Cells were exposed to the compounds for $24 \mathrm{~h}$. $* P<0.05$; $* * P<0.01$. (B) Promoter activity of the pGL3-OB1 $(2 \mu \mathrm{g})$ construct was analyzed in 3T3-L1 preadipocytes. Luciferase activity was determined in cells cotransfected with either $2 \mu \mathrm{g}$ of pSGS-cgPPAR $\gamma$ or the empty pSG5 expression vector in the presence or absence of 10 $\mu$ M BRL 49653. Cells were exposed to BRL 49653 for $24 \mathrm{~h}$. The mean of four points is shown. Experiments were performed at least three times. $* P<0.05$.

presence of saturating amounts of endogenous PPAR $\gamma$ in the mature adipocyte (Fig. $5 \mathrm{~A}$ ).

Treatment of undifferentiated 3T3-L1 preadipocytes with thiazolidinediones by themselves had no effect on $o b$ promoter activity thereby indicating and confirming observations that these cells, unlike primary adipocytes, do not contain PPAR $\gamma$ (38). Cotransfection of PPAR $\gamma$ in undifferentiated 3T3-L1 cells, however, consistently reduced the activity of the pGL3-OB1 promoter construct (Fig. 5 B). The degree of inhibition was dependent on the amount of PPAR $\gamma$ cotransfected. Only a slight additional effect of addition of the PPAR $\gamma$ ligand BRL 49653 was observed (Fig. 5 B).

\section{Discussion}

The association of murine obesity with mutations in the $o b$ gene has generated intense interest in molecular studies aimed at delineating factors potentially involved in human obesity. In this study, we determined whether the expression of the $o b$ gene is under the control of PPAR $\gamma$, a key transcription factor involved in adipocyte-specific gene expression. PPREs have been characterized in several genes involved in the control of lipid and fatty acid metabolism (reviewed in reference 29). In addition, several key adipocyte genes have been shown to be induced by PPAR activators and to contain functional PPREs in their regulatory sequences (e.g., lipoprotein lipase, Schoonjans, K., and J. Auwerx, unpublished observations; 36, 38, 50, 51). Furthermore, it was recently reported that antidiabetic thiazolidinediones $(41,42)$ and prostaglandin derivatives $(42$, 52) are direct and specific ligands for $\operatorname{PPAR} \gamma_{2}$. The identification of prostaglandins as the endogenous PPAR $\gamma_{2}$ ligand and the capacity of other fatty acids to activate this transcription factor provides a mechanistic explanation of the ability of fatty acids $(38,53,54)$ and arachidonic acid $(55)$ to induce adipocyte differentiation.
Despite the fact that $o b$ expression is associated with the differentiated adipocyte phenotype and PPAR $\gamma$ is a key transcription factor triggering and maintaining this phenotype, PPAR $\gamma$ activation does not induce $o b$ expression. To the contrary, PPAR $\gamma$ ligands decrease $o b$ expression both when administered in vivo and when added to cultured adipocytes in vitro. Furthermore, PPAR $\gamma$ decreases transcription of a reporter gene driven by $\sim 3,000$ bp of the human $o b$ promoter. This negative effect on $o b$ gene expression appears to be specific for compounds capable of activating PPAR $\gamma$, since fenofibrate, a potent PPAR $\alpha$ activator, has no effect on $o b$ gene expression. PPARs heterodimerize with RXRs and these heterodimers exert their effects on transcription via interaction with a PPRE, composed of a direct repeat of the nuclear receptor hexanucleotide core recognition motif spaced by 1 nucleotide (reviewed in reference 29). We were unable to identify by homology search a consensus PPRE in the $o b$ gene promoter. In view of the rather unusual negative effects of PPAR $\gamma$ by thiazolidinediones on $o b$ gene transcription and the absence of a consensus PPRE, it will be important to identify the molecular mechanism underlying this negative regulation. This phenomenon is reminiscent of the negative effects of PPAR $\alpha$ modulators on apo C-III expression in the liver (49, 56). It is therefore tempting to speculate that the repressive effects of PPAR $\gamma$ on the human $o b$ gene promoter might be mediated through interactions with positive modulators of $o b$ transcription, such as $\mathrm{C} / \mathrm{EBP} \alpha$ or $\mathrm{Sp} 1$ (30).

The observed decrease in $o b$ gene expression after treatment with BRL 49653 in the presence of an increase in adipose tissue mass is very interesting and suggests that body mass and $o b$ gene expression can be regulated in opposite fashion (e.g., by pharmacological treatment with PPAR $\gamma$ activators). This situation is in contrast with both the overexpression of $o b$ mRNA observed in several obese animals, such as the $d b / d b$ mice, Zucker falfa rats, and VMH-lesioned rats $(5,13,24-28)$, and with the positive correlation between body mass index and $o b$ mRNA or plasma leptin observed in humans (19-23). The physiological importance of this discordance between $o b$ mRNA levels and adipose tissue mass after thiazolidinedione treatment is unclear at present. It is, however, tempting to speculate that the uncoupling of adipose tissue mass and $o b$ gene expression might be implicated in mediating the effects of thiazolidinediones on insulin resistance.

In vivo, PPAR's activities to reduce leptin levels may lead to increased caloric uptake, thus favoring energy storage into adipocytes. In that context, the effects of PPAR $\gamma$ modulators on $o b$ gene expression and other adipocyte-specific target genes, such as lipoprotein lipase (Schoonjans, K., and J. Auwerx, unpublished observations), fatty acid transporter protein (Martin, G., B. Staels, and J. Auwerx, unpublished observations), aP2 (39), and acyl-CoA synthetase $(36,51)$ will lead to increased energy uptake and storage in the adipocyte. The reduction in $o b$ gene expression after PPAR $y$ activation might therefore explain two well-known but ill-understood phenomena. First, the PPAR-mediated reduction in $o b$ gene expression might underly the increase in adipocyte differentiation and adiposity associated with treatment with thiazolidinedione antidiabetic agents (43-47). Results from our experiments confirm the adipose tissue weight gain in animals receiving BRL 49653, showing a significant dose-dependent increase in these animals. The absence of an effect on total body weight in this study, in contrast to other studies reported in the literature 
(57-59), is most likely due to the short time BRL 49653 was administered in our experiments. Second, it is tempting to speculate that the increase in fatty acids delivered to the adipocyte after a high-fat meal could be involved in stimulating adipose PPAR $\gamma$ activity. The ensuing decrease in $o b$ gene expression and leptin levels would be associated with a smaller suppression of appetite. In fact, clinical data have shown that high fat meals are known to be less satiating than equicaloric carbohydrate-rich meals $(60,61)$.

In conclusion, we have demonstrated that $o b$ gene expression is reduced both in vivo and in vitro by PPAR $\gamma$ activators. These compounds have a direct effect on the $o b$ promoter. Knowledge of sequence elements involved in this regulation and identification of factors such as PPAR $\gamma$ regulating $o b$ gene expression should be of major importance in our understanding of adipocyte physiology and obesity.

\section{Acknowledgments}

The technical help of Delphine Cayet, Odille Vidal, Patricia Hoener, and Jim Bilakovics and the support and/or discussions with Prof. Jean-Charles Fruchart of IPL, Drs. Rich Heyman, Ranjan Mukherjee, Dave Robertson, Robert Stein, and James Paterniti from Ligand Pharmaceuticals are kindly acknowledged. We acknowledge the gift of fenofibrate by Dr. Alan Edgar.

J. Auwerx is a research director and B. Staels a research associate from the CNRS. M. Guerre-Millo is a research director of INSERM.

\section{References}

1. Grundy, S.M., and J.P. Barnett. 1990. Metabolic and health complications of obesity. Disease-a-Month. 36:641-731.

2. Friedman, J.M., and R.L. Leibel. 1990. Tackling a weighty problem. Cell. 69:217-220.

3. Friedman, J.M., R.L. Leibel, D.S. Siegel, J. Walsh, and N. Bahary. 1991. Molecular mapping of the mouse $o b$ mutation. Genomics. 11:1054-1062.

4. Zhang, Y., R. Proenca, M. Maffei, M. Barone, L. Leopold, and J.M. Friedman. 1994. Positional cloning of the mouse obese gene and its human homolog. Nature (Lond.). 372:425-432.

5. Halaas, J.L., K.S. Gajiwala, M. Maffei, S.L. Cohen, B.T. Chait, D. Rabinowitz, R.L. Lallone, S.K. Burley, and J.M. Friedman. 1995. Weightreducing effects of the plasma protein encoded by the obese gene. Science (Wash. DC). 269:543-546.

6. Coleman, D.L. 1978. Obese and diabetes: two mutant genes causing diabetes-obesity syndromes in mice. Diabetologia. 14:141-148.

7. Campfield, L.A., F.J. Smith, Y. Guisez, R. Devos, and P. Burn. 1995. Recombinant mouse OB protein; evidence for a peripheral signal linking adiposity and central neural networks. Science (Wash. DC). 269:546-549.

8. Pelleymounter, M.A., M.J. Cullen, M.B. Baker, R. Hecht, D. Winters, T. Boone, and F. Collins. 1995. Effect of the obese gene product on body weight regulation in ob/ob mice. Science (Wash. DC). 269:540-543.

9. Weigle, D.S., T.R. Bukowski, D.C. Foster, S. Holderman, J.M. Kramer, G. Lasser, C.E. Lofton-Day, D.E. Prunkard, C. Raymond, and J.L. Kuijper. 1995. Recombinant $o b$ protein reduces feeding and body weight in the $o b / o b$ mouse. J. Clin. Invest. 96:2065-2070.

10. Rentsch, J., N. Levens, and M. Chiesi. 1995. Recombinant $o b$ gene product reduces food intake in fasted mice. Biochem. Biophys. Res. Commun. 214: 131-136.

11. Tartaglia, L.A., M. Dembski, X. Weng, N. Deng, J. Culpepper, R. Devos, G.J. Richards, L.A. Campfield, F.T. Clark, J. Deeds, et al. 1995. Identification and expression cloning of a leptin receptor, OB-R. Cell. 83:1263-1271.

12. Lee, G.H., R. Proenca, J.M. Montez, K.M. Carroll, J.G. Darvishzadeh, J.I. Lee, and J.M. Friedman. 1996. Abnormal splicing of the leptin receptor in diabetic mice. Nature (Lond.). 379:632-635.

13. Frederich, R.C., B. Lollmann, A. Hamann, A. Napolitano-Rosen, B.B. Kahn, B.B. Lowell, and J.S. Flier. 1995. Expression of $o b$ mRNA and its encoded protein in rodents. Impact of nutrition and obesity. J. Clin. Invest. 96: 1658-1663.

14. MacDougald, O.A., C.S. Hwang, H. Fan, and M.D. Lane. 1995. Regulated expression of the obese gene product (leptin) in white adipose tissue and 3T3-L1 adipocytes. Proc. Natl. Acad. Sci. USA. 92:9034-9037.

15. Trayhurn, P., M.E.A. Thomas, J.S. Duncan, and V.D. Rayner. 1995. Effect of fasting and refeeding on $o b$ gene expression in white adipose tissue of lean and (ob/ob) mice. FEBS Lett. 368:488-490.

16. Saladin, R., P. De Vos, M. Guerre-Millo, A. Leturque, J. Girard, B Staels, and J. Auwerx. 1995. Transient increase in obese gene expression after food intake and insulin administration. Nature (Lond.). 377:527-529.

17. De Vos, P., R. Saladin, J. Auwerx, and B. Staels. 1995. Induction of $o b$ gene expression by corticosteroids is accompanied by body weight loss and reduced food intake. J. Biol. Chem. 270:15958-15961.

18. Murakami, T., M. Iida, and K. Shima. 1995. Dexamethasone regulates obese expressioin in isolated rat adipocytes. Biochem. Biophys. Res. Commun. 214:1260-1267.

19. Considine, R.V., E.L. Considine, C.J. Williams, M.R. Nyce, S.A. Magosin, T.L. Bauer, E.L. Rosato, J. Colberg, and J.F. Caro. 1995. Evidence against either a premature stop codon or the absence of obese gene mRNA in human obesity. J. Clin. Invest. 95:2986-2988.

20. Lönnqvist, F., P. Arner, L. Nordfors, and M. Schalling. 1995. Overexpressioin of the obese $(o b)$ gene in adipose tissue of human obese subjects. Nat. Med. 1:950-953.

21. Hamilton, B.S., D. Ivaglia, A.Y.M. Kwan, and M. Deitel. 1995. Increased obese mRNA expression in omental fat cells from massively obese humans. Nat. Med. 1:954-956.

22. Maffei, M., J. Halaas, E. Ravussin, R.E. Pratley, G.H. Lee, Y. Zhang, H Fei, S. Kim, R. Lallone, S. Ranganathan, et al. 1995. Leptin levels in human and rodent: measurement of plasma leptin and $o b$ RNA in obese and weight-reduced subjects. Nat. Med. 1:1155-1161.

23. Considine, R.V., M.K. Sinha, M.L. Heiman, A. Kriauciunas, T.W. Stephens, M.R. Nyce, J.P. Ohannesian, C.C. Marco, L.J. McKee, T.L. Bauer, and J.F. Caro. 1996. Serum-immunoreactive leptin concentrations in normalweight and obese humans. N. Engl. J. Med. 334:292-295.

24. Murakami, T., and K. Shima. 1995. Cloning of rat obese cDNA and its expression in obese rats. Biochem. Biophys. Res. Commun. 209:944-952.

25. Funahashi, T., I. Shimomura, H. Hiraoka, T. Arai, M. Takahashi, T. Nakamura, S. Nozaki, S. Yamashita, K. Takemura, K. Tokunaga, and Y. Matsuzawa. 1995. Enhanced expression of rat obese $(o b)$ gene in adipose tissues of ventromedial hypothalamus (VMH)-lesioned rats. Biochem. Biophys. Res. Commun. 211:469-475.

26. Ogawa, Y., H. Masuzaki, N. Isse, T. Okazaki, K. Mori, M. Shigemoto, N. Satoh, N. Tamura, K. Hosoda, Y. Yoshimasa, et al. 1995. Molecular cloning of rat obese cDNA and augmented gene expression in genetically obese Zucker fatty (falfa) rats. J. Clin. Invest. 96:1647-1652.

27. Maffei, M., H. Fei, G.-H. Lee, C. Dani, P. Leroy, Y. Zhang, R. Proenica, R. Negrel, G. Ailhaud, and J.M. Friedman. 1995. Increased expression in adipocytes of $o b$ RNA in mice with lesions of hypothalamus and with mutations in the $d b$ locus. Proc. Nat. Acad. Sci. USA. 92:6957-6960.

28. Masuzaki, H., K. Hosoda, Y. Ogawa, M. Shigemoto, N. Satoh, K. Mori, N. Tamura, S. Nishi, Y. Yoshimas, Y. Yamori, and K. Nakao. 1996. Augmented expression of obese $(o b)$ gene during the process of obesity in genetically obesehyperglycemic Wistar (falfa) rats. FEBS Lett. 378:267-271.

29. Schoonjans, K., B. Staels, and J. Auwerx. 1996. Role of the peroxisome proliferator activated receptor (PPAR) in mediating effects of fibrates and fatty acids on gene expression. J. Lipid Res. 37:907-925.

30. Miller, S.G., P. De Vos, M. Guerre-Millo, K. Wong, T. Hermann, B. Staels, M.R. Briggs, and J. Auwerx. 1996. The adipocyte-specific transcription, $\mathrm{C} / \mathrm{EBP} \alpha$ modulates human $o b$ gene expression. Proc. Nat. Acad. Sci. USA. 93: 5507-5511.

31. He, Y., H. Chen, M.J. Quon, and M. Reitman. 1995. The mouse obese gene. Genomic organization, promoter activity, and activation by CCAAT/enhancer-binding protein alpha. J. Biol. Chem. 270:28887-28891.

32. Hajduch, E.J., M. Guerre-Millo, I.A. Hainault, C.M. Guichard, and M.M. Lavau. 1992. Expression of glucose transporters (GLUT1 and GLUT4) in primary cultured rat adipocytes: differential evolution with time and chronic insulin effect. J. Cell. Biochem. 49:251-258.

33. Cleveland, D.W., M.A. Lopata, R.J. McDonald, M.J. Cowan, W.J. Rutter, and M.W. Kirschner. 1980. Number and evolutionary conservation of $\alpha$ - and $\beta$-tubulin and cytoplasmic $\beta$ - and $\gamma$-actin genes using specific cloned cDNA probes. Cell. 20:95-105.

34. Henikoff, S. 1984. Unidirectional digestion with exonuclease III creates targeted breakpoints for DNA sequencing. Gene. 28:351-359.

35. Aperio, C., P. Pognonec, R. Saladin, J. Auwerx, and K. Boulukos. 1995. Isolation and characterization of the hamster peroxisomal proliferator activated receptor hPPAR $\gamma$, a member of the nuclear hormone receptor superfamily. Gene. 162:297-302.

36. Schoonjans, K., M. Watanabe, H. Suzuki, A. Mahfoudi, G. Krey, W. Wahli, P. Grimaldi, B. Staels, T. Yamamoto, and J. Auwerx. 1995. Induction of the Acyl-Coenzyme A synthetase gene by fibrates and fatty acids is mediated by a peroxisome proliferator response element in the $\mathrm{C}$ promoter. J. Biol. Chem. 270:19269-19276.

37. Quon, M.J., M.J. Zarnowski, M. Guerre-Millo, M. Luz Sierra, S.I. Taylor, and S.W. Cushman. 1993. Transfection of DNA into isolated rat adipose cells by electroporation. Biochem. Biophys. Res. Commun. 194:338-346.

38. Tontonoz, P., E. Hu, and B.M. Spiegelman. 1994. Stimulation of adipogenesis in fibroblasts by PPAR $\gamma 2$, a lipid-activated transcription factor. Cell. 79: 1147-1156. 
39. Tontonoz, P., E. Hu, R.A. Graves, A.I. Budavari, and B.M. Spiegelman. 1994. mPPAR $\gamma 2$ : tissue-specific regulator of an adipocyte enhancer. Genes \& Dev. 8:1224-1234

40. Darlington, G.J., N. Wang, and R.W. Hanson. 1995. C/EBP $\alpha$ : a critical regulator of genes governing metabolic processes. Curr. Opin. Genet. \& Dev. 5 : $565-570$

41. Lehmann, J., L.B. Moore, T.A. Smith-Oliver, W.O. Wilkison, T.M. Willson, and S.A. Kliewer. 1995. An antidiabetic thiazolidinedione is a high affinity ligand for peroxisome proliferator-activated receptor $\gamma(\operatorname{PPAR} \gamma)$. J. Biol. Chem. 270:12953-12956.

42. Forman, B.M., P. Tontonoz, J. Chen, R.P. Brun, B.M. Spiegelman, and R.M. Evans. 1995. 15-Deoxy- $\Delta 12,14$ prostaglandin J2 is a ligand for the adipocyte determination factor PPAR $\gamma$. Cell. 83:803-812.

43. Hiragun, A., M. Sato, and H. Mitsui. 1988. Preadipocyte differentiation in vitro: identification of a highly active adipogenic agent. J. Cell. Physiol. 134: 124-130.

44. Sparks, R.L., E.E. Strauss, A.I. Zygmunt, and T.E. Phelan. 1991. Antidiabetic AD4743 enhances adipocyte differentiation of 3T3 T mesenchymal stem cells. J. Cell. Physiol. 146:101-109.

45. Kletzien, R.F., S.D. Clarke, and R.G. Ulrich. 1992. Enhancement of adipocyte differentiation by an insulin sensitizing agent. Mol. Pharmacol. 41:393398.

46. Sandouk, T., D. Reda, and C. Hofmann. 1993. Antidiabetic agent pioglitazone enhances adipocyte differentiation of 3T3-F442A cells. Am. J. Physiol. 264:C1600-C1608.

47. Teboul, L., D. Gaillard, L. Staccini, H. Inadera, E.Z. Amri, and P. Grimaldi. 1995. Thiazolidinediones and fatty acids convert myogenic cells into adipose-like cells. J. Biol. Chem. 270:28137-28183.

48. Staels, B., A. Van Tol, T. Andreu, and J. Auwerx. 1992. Fibrates influence the expression of genes involved in lipoprotein metabolism in a tissueselective manner in the rat. Arterioscler. Thromb. 12:286-294.

49. Staels, B., N. Vu-Dac, V. Kosykh, R. Saladin, J.C. Fruchart, J. Dallongeville, and J. Auwerx. 1995. Fibrates down-regulate apolipoprotein C-III expression independent of induction of peroxisomal Acyl coenzyme A oxidase. $J$. Clin. Invest. 95:705-712.

50. Tontonoz, P., E. Hu, J. Devine, E.G., Beale, and B.M. Spiegelman. 1995. PPAR $\gamma 2$ regulates adipose expression of the phosphoenolpyruvate carboxykinase gene. Mol. Cell. Biol. 15:351-357.
51. Schoonjans, K., B. Staels, P. Grimaldi, and J. Auwerx. 1993. Acyl-CoA synthetase mRNA expression is controlled by fibric-acid derivatives, feeding and liver proliferation. Eur. J. Biochem. 216:615-622.

52. Kliewer, S.A., J.M. Lenhard, T.M. Willson, I. Patel, D.C. Morris, and J.M. Lehman. 1995. A prostaglandin J2 metabolite binds peroxisome proliferator-activated receptor $\gamma$ and promotes adipocyte differentiation. Cell. 83:813819

53. Amri, E.-Z., B. Bertrand, G. Ailhaud, and P. Grimaldi. 1991. Regulation of adipose cell differentiation. I. Fatty acids are inducers of the aP2 gene expression. J. Lipid Res. 32:1449-1456.

54. Chawla, A., and M.A. Lazar. 1994. Peroxisome proliferator and retinoid signaling pathways co-regulate preadipocyte phenotype and survival. Proc. Natl. Acad. Sci. USA. 91:1786-1790.

55. Gaillard, D., R. Negre, M. Lagarde, and G. Ailhaud. 1989. Requirement and role of arachidonic acid in the differentiation of pre-adipose cells. Biochem. J. 257:389-397.

56. Hertz, R., J. Bishara-Shieban, and J. Bar-Tana. 1995. Mode of action of peroxisome proliferators as hypolipidemic drugs, suppression of apolipoprotein C-III. J. Biol. Chem. 270:13470-13475.

57. Ikeda, H., S. Taketomi, Y. Sugiyama, Y. Shimura, T. Sohda, K. Meguro, and T. Fujita. 1990. Effects of pioglitazone on glucose and lipid metabolism in normal and insulin resistant animals. Drug Res. 40:156-162.

58. Castle, C.K., J.R. Colca, and G.W. Melchior. 1993. Lipoprotein profile characterization of the KKAy mouse, a rodent model of type II diabetes, before and after treatment with the insulin-sensitizing agent pioglitazone. Arterioscler. Thromb. 13:302-309.

59. Hirshman, M.F., P.M. Fagnant, E.D. Horton, P.A. King, and E.S. Horton. 1995. Pioglitazone treatment for 7 days failed to correct the defect in glucose transport and glucose transporter translocation in obese Zucker rat ( $f a / f a$ ) skeletal muscle plasma membranes. Biochem. Biophys. Res. Commun. 208:835845 .

60. Blundell, J.E., V.J. Burley, J.R. Cotton, and C.L. Lawton. 1993. Dietary fat and the control of energy intake: evaluating the effects of fat on meal size and postmeal satiety. Am. J. Clin. Nutr. 57:772-778.

61. Rolls, B.J., S. Kim-Harris, M.W. Fischman, R.W. Foltin, T.H. Moran, and S.A. Stoner. 1994. Satiety after preloads with different amounts of fat and carbohydrate: implications for obesity. Am. J. Clin. Nutr. 60:476-487. 